\title{
Intake, performance, digestibility, microbial efficiency and carcass characteristics of growing Nellore heifers fed two concentrate levels ${ }^{1}$
}

\author{
Mateus Pies Gionbelli ${ }^{2}$, Sebastião de Campos Valadares Filho ${ }^{3}$, Edenio Detmann ${ }^{3}$, Pedro \\ Veiga Rodrigues Paulino ${ }^{3}$, Rilene Ferreira Diniz Valadares ${ }^{4}$, Tathyane Ramalho Santos ${ }^{2}$, Luiz \\ Fernando Costa e Silva ${ }^{2}$, Felipe Antunes Magalhães ${ }^{5}$
}

\footnotetext{
${ }^{1}$ Research financed by CNPq and INCT-Ciência Animal.

2 Programa de Pós-Graduação em Zootecnia, Universidade Federal de Viçosa, Viçosa-MG, 36571-000.

${ }^{3}$ Departamento de Zootecnia, Universidade Federal de Viçosa, Viçosa-MG, 36571-000. Researcher at CNPq and INCT-Ciência Animal.

${ }^{4}$ Departamento de Medicina Veterinária, Universidade Federal de Viçosa, Viçosa-MG, 36571-000. Researcher at CNPq and INCT-Ciência Animal.

5 Programa de Pós-Graduação em Zootecnia, Universidade Federal de Minas Gerais, Belo Horizonte- MG, 30123-970.
}

ABSTRACT - The objective of this study was to evaluate nutrients and dry matter intake, average daily gain, feed efficiency and digestibility of diets, microbial efficiency, cold carcass yield and basic cuts yields of young Nellore heifers receiving two concentrate levels. Nineteen heifers with initial average weight of $165.6 \pm 29.8 \mathrm{~kg}$ were used. Three animals were used in a trial to determine the digestibility and microbial efficiency of the two levels of concentrate $(225 \mathrm{and} 450 \mathrm{~g} / \mathrm{kgDM})$ and a treatment with a restricted intake maintenance level. The remaining 16 heifers were confined for 168 days for evaluation of performance and intake, divided into two levels of concentrate. Every 42 days, four animals, two from each concentrate level, were slaughtered to determine carcass characteristics, making a $2 \times 4$ factorial arrangement. Digestibility and microbial efficiency were not affected by concentrate level or intake level, both for ad libitum and restricted feeding. Heifers fed $450 \mathrm{~g} / \mathrm{kgDM}$ concentrate diet had greater average daily gain than those fed $225 \mathrm{~g} / \mathrm{kgDM}$ concentrate. Dry matter intake and feed efficiency did not differ between levels of concentrate. Average daily gain ( $\mathrm{kg} /$ day), dry matter intake (\% body weight/day) and feed efficiency were higher in the first period of feedlot (0-42 days) compared with the other (42 to 168 days). Heifers fed $450 \mathrm{~g} / \mathrm{kgDM}$ concentrate had greater average daily gain than those fed $225 \mathrm{~g} / \mathrm{kgDM}$ concentrate.

Key Words: beef heifers, concentrate level, feedlot, growth, maturity, weight gain

\section{Introduction}

In the year 2010, the slaughter of heifers in Brazil corresponded to $6.2 \%$ of the total of animals slaughtered (IBGE, 2011). Although it is still a relatively low number, the use of different genders, along with direct handling, represents an available tool for the farmer, in a way to obtain an association that brings them better productive and economical efficiency, within the production reality (Paulino et al., 2008). Besides, it is worth stressing that females present potential to reach maturity earlier, achieving backfat thickness equal or greater than males with lower weights (Coutinho Filho et al., 2006).

Another interesting aspect to be taken into account is the possibility of beef heifers mating for the first time at 1415 months of age, once there is higher biological efficiency on females that calve for the first time at two years old (Pötter et al., 1998; Rocha \& Lobato, 2002). There is also greater profitability potential, for the cow could produce more kilograms of calves throughout its life. For this goal to be reached, knowledge that enables the optimization of the nutritional management and that improves the performance of females at the post-weaning stage becomes necessary.

The magnitude of the influence that feedlot time has on animal performance depends, mostly, on the nutritional level to which these animals are subjected before and during feedlot. Thus, it is necessary to set a feed management that enables integrating lower costs to better productive results, meeting the market demands.

Based on this, the objective of this study was to evaluate intake, weight gain, feed efficiency, digestibility, microbial efficiency and carcass and basic cuts yields of feedlot Nellore heifers.

\section{Material and Methods}

The research was carried out at the Laboratory of Animals from the Department of Animal Science of Universidade Federal de Viçosa. Nineteen Nellore heifers, 
from a contemporary group, with average initial age of 10 months and initial weight of $165.6( \pm 29.8) \mathrm{kg}$ were used.

Three heifers were randomly chosen and subjected to an experiment for assessment of digestibility of diets and microbial efficiency (experiment I) and 16 heifers underwent an experiment for evaluation of performance, intake, feed efficiency and carcass and cuts yields (experiment II).

Experiment I was conducted in a $3 \times 3$ Latin square. Initially, animals were weighted, indentified and treated against ecto- and endoparasites, then kept in tie stall-type feedlot, in covered pens with rubber-lined floor, with $9-\mathrm{m}^{2}$ area, provided with individual feeders and automatic drinkers. Animals underwent a 21-day period of adaptation.

The three treatments applied to animals corresponded to two concentrate levels in the diet: 225 and $450 \mathrm{~g} / \mathrm{kg}$ of dry matter (DM), and a treatment where animals were fed at maintenance level, receiving the diet with the lowest concentrate level in restricted intake $(1.1 \%$ of the body weight, on a DM basis). The utilization of the treatment at maintenance level was due to the fact that the animals from this study had also been utilized for an experiment of evaluation of nutritional requirements.

Corn silage was used as roughage, and the concentrates were formulated based on ground corn, soybean meal, wheat bran, urea, ammonium sulfate, limestone, salt and mineral mixture (Table 1). Concentrates were formulated to make the diets isoprotein, with $130 \mathrm{~g} / \mathrm{kgDM}$ of crude protein (CP), with the same proportions of corn and soybean meal found in the two concentrates maintained, with variation in the amount of urea and ammonium sulfate; wheat bran was used to complete the formulation (Table 2).

Each of the three experimental periods had a duration of 35 days, and at the end of the fifth week of each period, measuring of intake (with sampling of the feed supplied and orts) was performed for five days, and total collection of feces and urine, for three consecutive days. The duration of 35 days for each period was adopted for the animals of this experiment to follow the growth of animals from experiment II, so that the digestibility study could have duration close to experiment II.

Feed was supplied twice daily and adjusted so that orts were kept at around 5 to $10 \%$ the total supplied ad libitum, with water permanently at the disposal of the animals. In each period, during the adaptation to the diets, the animal in the maintenance level only had restricted feeding on the last two weeks of the period, so that, due to the long periods of adaptation the animal would not have its growth damaged and could follow the growth of the others.

Corn silage and orts of each animal were sampled daily and conditioned in freezer $\left(-15^{\circ} \mathrm{C}\right)$. At the end of each collection period, samples were oven-dried $\left(60^{\circ} \mathrm{C}\right)$ and ground in knife mill with 1-mm sieve. After, the total dry matter of these samples was measured by means of oven drying $\left(105^{\circ} \mathrm{C} / 16\right.$ hours $)$.

Samples of orts, corn silage, feces and ingredients of the concentrates were quantified as for the contents of dry matter (DM), mineral matter (MM), total nitrogen and ether extract (EE), according to recommendations by Silva \& Queiroz (2002). The content of neutral detergent fiber (NDF) was obtained according to method described by Van Soest et al. (1991), with addition of sodium sulfite (Undersander et al., 1993) for analyses of soybean meal, because of the gelatinization of the protein content. Ankom ${ }^{\circledR}$ system was utilized for NDF evaluations, with heat-stable $\alpha$-amylase addition and modification of the bag utilized $(5.0 \times 5.0 \mathrm{~cm}$, $100 \mu \mathrm{m}$ porosity), which was manufactured using nonwoven

Table 1 - Chemical composition of ingredients utilized in the experimental diets

\begin{tabular}{|c|c|c|c|c|c|c|c|c|}
\hline $\begin{array}{l}\text { It em } \\
(\mathrm{g} / \mathrm{kgDM})\end{array}$ & Corn silage & Ground corn & Soybean meal & Wheat bran & Urea/AS ${ }^{1}$ & Limestone & Salt & Mineral mixture \\
\hline DM & 255.8 & 865.6 & 863.8 & 865.2 & 973.3 & 998.5 & 955.9 & 960.9 \\
\hline $\mathrm{OM}^{2}$ & 942.5 & 986.6 & 937.7 & 941.1 & - & - & 1.2 & - \\
\hline $\mathrm{CP}^{2}$ & 76.3 & 94.5 & 524.8 & 169.9 & 2658.0 & - & - & - \\
\hline $\mathrm{NDIP} / \mathrm{CP}^{3}$ & 153.0 & 175.0 & 24.7 & 106.4 & - & - & - & - \\
\hline $\mathrm{EE}^{2}$ & 27.7 & 33.9 & 23.7 & 49.6 & - & - & - & - \\
\hline $\mathrm{NDF}^{2}$ & 562.0 & 121.4 & 120.9 & 452.4 & - & - & - & - \\
\hline $\mathrm{NDF}_{\mathrm{ap}}{ }^{2}$ & 526.1 & 93.3 & 103.9 & 430.1 & - & - & - & - \\
\hline $\mathrm{NFC}^{2^{\mathrm{ap}}}$ & 312.4 & 764.9 & 285.4 & 291.4 & - & - & - & - \\
\hline $\mathrm{Ca}^{2}$ & 1.8 & 0.5 & 4.0 & 2.2 & - & 375.4 & 1.1 & 300.3 \\
\hline $\mathrm{P}^{2}$ & 3.0 & 1.9 & 5.3 & 28.2 & - & 0.1 & - & 189.0 \\
\hline $\mathrm{Mg}^{2}$ & 1.2 & 1.0 & 3.3 & 4.7 & - & 11.6 & 0.3 & 8.6 \\
\hline $\mathrm{Na}^{2}$ & 0.8 & 0.9 & 1.3 & 1.6 & - & - & 373.9 & 2.3 \\
\hline $\mathrm{K}^{2}$ & 12.1 & 3.8 & 27.8 & 15.1 & - & - & - & 3.1 \\
\hline
\end{tabular}

DM - dry matter; OM - organic matter; CP - crude protein; NDIP/CP - neutral detergent insoluble protein by crude protein unit; EE - ether extract; NDF - neutral detergent fiber; $\mathrm{NDF}_{\mathrm{ap}}$ - neutral detergent fiber corrected for ash and protein; NFC - non-fibrous carbohydrates.

${ }^{1}$ Urea + ammonium sulfate mixture at a 9:1 ratio, with $47.25 \%$ urea $\mathrm{N}$ content.

$2 \mathrm{~g} / \mathrm{kg}$ of DM.

$3 \mathrm{~g} / \mathrm{kg}$ of CP. 
Table 2 - Ingredient levels in concentrate and diets and concentrate composition and diets results, on a dry matter basis

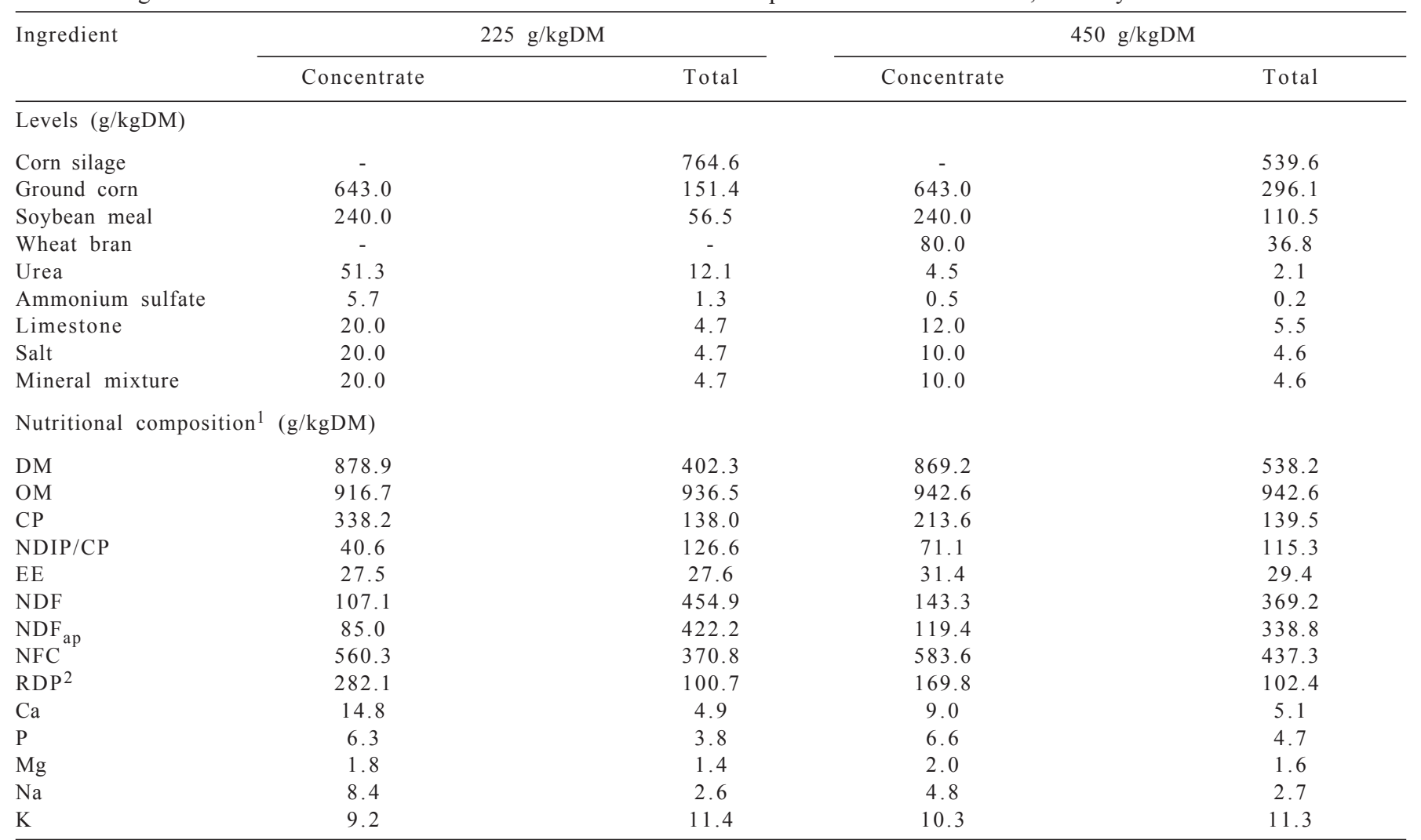

DM - dry matter; OM - organic matter; CP - crude protein; NDIP/CP - neutral detergent insoluble protein by crude protein unit; EE - ether extract; NDF - neutral detergent fiber; $\mathrm{NDF}_{\mathrm{ap}}$ - neutral detergent fiber corrected for ash and protein; NFC - non-fibrous carbohydrates; RDP - ruminal undegradable protein.

1 Analyzed values.

2 Estimated values (NRC, 2001).

fabric $\left(100 \mathrm{~g} / \mathrm{m}^{2}\right)$. In all the samples, NDF content was corrected for ash and protein $\left(\mathrm{NDF}_{\mathrm{ap}}\right)$.

Non-fibrous carbohydrates (NFC) were calculated as suggested by Detmann \& Valadares Filho et al. (2010), where $\mathrm{NFC}=100-[(\% \mathrm{CP}-\% \mathrm{CP}$ derived from urea $+\%$ urea $)$ $\left.+\mathrm{NDF}_{\mathrm{ap}}+\mathrm{EE}+\% \mathrm{ash}\right]$.

The collected feces were weighted, homogenized and sampled at every 24 hours. Subsequently, they were ovendried $\left(60^{\circ} \mathrm{C}\right)$, then ground through knife mill $(1 \mathrm{~mm})$, with one sample of feces per animal created, corresponding to the three collection days.

Microbial protein production was estimated from the technique of the purine derivatives in urine (Chen \& Gomes, 1992).

For urine collection, two-way Folley catheters no. 22, with $30-\mathrm{mL}$ balloon were inserted directly into heifers bladders. At the free extremity of the catheter, polyethylene tube was connected to conduct the urine to plastic covered tanks containing $200 \mathrm{~mL} \mathrm{H}_{2} \mathrm{SO}_{4}(20 \%)$, in order to keep the final $\mathrm{pH}$ of the urine below 3 . Collections were performed for three consecutive days in each period, concomitantly with feces collection. At the end of each 24 hours, weight and total volume of the urine excreted were evaluated, then urine was homogenized for obtainment of $10-\mathrm{mL}$ samples, which were diluted with $40 \mathrm{~mL} \mathrm{H}_{2} \mathrm{SO}_{4} 0.036 \mathrm{~N}$, aiming at the avoidance of bacterial destruction of purine derivatives in urine and precipitation of the uric acid. A composite sample of urine from the three collection days was obtained without dilution for evaluation of urea and creatitine. All samples were stored at $-15{ }^{\circ} \mathrm{C}$ for further laboratory analyses.

Analyses of allantoin in the urine were done by colorimetric method, according to technique of Fujihara et al. (1987), described by Chen \& Gomes (1992). For quantification of uric acid in the urine, the enzymatic endpoint system was utilized, following the uricase principle - the Trinder reaction, utilizing commercial kits from Labtest Diagnóstica Inc. (ref. 73). Both urine analyses were performed in the diluted samples.

Excretion of the purine derivatives in urine was calculated by the sum of the allantoin and uric acid excretions, which were obtained by the product between their concentrations in urine by the daily urinary volume. Absorbed purines were calculated from the excretion of purine derivatives (PD) by means of the following equation (Barbosa et al., 2011): 


$$
Y=\frac{X-0.301 \times B W^{0.75}}{0.8}
$$

where $\mathrm{Y}=$ absorbed purines $(\mathrm{mmol} / \mathrm{day}), \mathrm{X}=$ excretion of purine derivates $(\mathrm{mmol} /$ day $), 0.8=$ recovered absorbed purines. This equation was modified from the study of Barbosa et al. (2011), where the 0.74 value in the original study was divided by the value of true purine absorption value in the small intestine, of 0.9278 , to obtain the true value of recovered of absorbed purines. The $0.301 \times \mathrm{BW}^{0.75}$ value $=$ endogenous excretion of PD. Ruminal synthesis of nitrogen compounds was calculated in function of the absorbed purines, through the following equation (Barbosa et al., 2011):

$$
Y=\frac{70 \times X}{0.93 \times 0.1369 \times 1000}
$$

where $\mathrm{Y}=$ ruminal synthesis of nitrogen compounds $(\mathrm{N} /$ day, $\mathrm{g}), \mathrm{X}=$ absorbed purines ( $\mathrm{mmol} /$ day), $70=$ purine $\mathrm{N}$ content $(\mathrm{mgN} / \mathrm{mol}), 0.93=$ purine digestibility and $0.1369=$ relation of purine $\mathrm{N}$ :total $\mathrm{N}$ of microorganisms.

Comparisons were realized by means of orthogonal contrasts, with one contrast performed to verify possible differences for the traits evaluated between levels 225 and $450 \mathrm{~g} / \mathrm{kg}$ DM of concentrate in the diet, and another between treatments ad libitum and restricted intake at maintenance level. Statistical analysis was performed using PROC GLM of SAS, by adopting $5 \%$ as critical probability level for type I error.

In the second experiment, the 16 heifers were weighed, identified and treated against ecto- and endoparasites, and subsequently housed in individual pens with concrete floor, provided with concrete feeder and drinker, with a total area of $30 \mathrm{~m}^{2}$, with $8 \mathrm{~m}^{2}$ covered area. All animals went through pre-experimental period of 21 days for adaptation to experimental conditions, where they received the same diet, with intermediate chemical composition between the diets utilized in the experiment $(350 \mathrm{~g} / \mathrm{kg}$ DM of concentrate).

Heifers were randomly divided in two groups: eight were fed a diet containing $225 \mathrm{~g} / \mathrm{kg}$ DM of concentrate, on a dry matter basis, and the other eight with $450 \mathrm{~g} / \mathrm{kg}$ DM of concentrate on, a DM basis. These were the same diets from experiment I (Table 2).

Experiment II was done in a completely randomized design, in a $2 \times 4$ factorial arrangement, which were two concentrate levels and four feedlot times. The total length of the experiment was 168 days, divided in four 42-day periods. At the end of every 42 days, animals were weighed, and four animals, two from each concentrate level, randomly chosen, were slaughtered for evaluation of carcass characteristics. This way, from the 16 animals, four were slaughtered at 42 days, four at 84 days, four at 126 days and another four at 168 days.

Feed was supplied twice daily, and the supply was adjusted so that orts were kept at around 5 to $10 \%$ the total supplied, with permanent water at the disposal of the animals. The amount of corn silage and concentrate supplied, as well as orts, were recorded and sampled daily, following the same procedure described for Experiment I.

Chemical analyses were performed according to procedures described for experiment I. Total digestible nutrients intake was calculated from the digestibility coefficients from diets obtained in experiment I.

Before slaughter, animals were submitted to solids fast for 16 hours. The slaughter was performed via stunning and incision of the jugular vein for total bleeding. Carcasses of all the animals were split, and half-carcasses were weighted and chilled in cold chamber $\left(-5^{\circ} \mathrm{C}\right)$ for approximately 24 hours. After chilled, carcasses were weighed once more for evaluation of cold carcass yield; backfat thickness at the 12 th rib height was also measured. In the right half of the carcass, basic commercial cut yields were measured, separating the forequarter and hindquarter by cutting between the fifth and sixth ribs. The forequarter consisted of the chuck, shoulder and flank, and the hindquarter consisted of top sirloin and rump. Commercial cuts were weighed and evaluated relatively (in relation to carcass weight).

For evaluations of cold carcass yield, basic cuts yield and backfat thickness, the PROC GLM feature of SAS was used, and comparisons between concentrate levels and interaction between concentrate levels and feedlot time were done by means of variance analysis. Feedlot times were evaluated by means of orthogonal contrasts to verify linear, quadratic or cubic effect.

As there was high variability of weight between the animals slaughtered at the end of each period, within each treatment, multiple regression equations of the variables analyzed were also tested, in function of the animal weight at slaughter and concentrate level. A critical probability level of 5\% was adopted for type I error in all the tests realized.

Due to the slaughter of four animals, two of each treatment, at every 42 days, periods started to have a different number of repetitions, which enabled only comparison of the concentrate levels within each period, without the comparison between periods in the traditional way. Because of this, data on intake and performance during the periods were considered repeated measures over time, with the data being evaluated by mixed models utilizing the PROC MIXED feature of SAS, in which the animal was 
considered random effect, and the treatment and period, fixed effects. This procedure allowed measuring the variability existing within and between periods, even with unequal number of replicates.

The method for estimation of variance components utilized was REML (restricted or residual maximum likelihood). The following types were tested as covariance and variance matrices for random effects: compound symmetric (homogeneous variance and null variance), heterogeneous compound symmetric (heterogeneous variance and null covariance), non-structured (heterogeneous variance and covariance) and autoregressive (homogeneous variance and covariance). For each variable analyzed, the matrix which presents the lowest value for the Akaike criterion information (AIC) was adopted (Akaike, 1974).

Comparisons between treatments were done by means of variance analyses, whereas comparisons between periods were carried out through the Tukey-Kramer test, with critical probability level $5 \%$ adopted for type I error in all the tests.

\section{Results and Discussion}

No differences were observed $(\mathrm{P}>0.05)$ in the digestibility coefficients of dry matter and other nutrients between treatments (Table 3 ). In the literature contradictory results are observed for digestibility values at different concentrate levels and in restricted intake; many times this digestibility is directly affected by the amount of roughage utilized. Paulino et al. (2008) found increase in apparent digestibility of diets of animals which received $1.2 \% \mathrm{BW}$ in concentrate in relation to those which received $0.6 \%$. However, these authors did not observe differences $(\mathrm{P}>0.05)$ in the apparent digestibility coefficients of the diet components, which demonstrates that the digestibility of a diet as a whole is the balance of interactive and associative effects of all the diet components and not of the isolate effect of a certain constituent.

No differences were observed ( $\mathrm{P}>0.05)$ for any of the variables assessed by urine when compared between concentrate levels. Nevertheless, when the two levels of intake were compared, it could be observed that animals fed ad libitum presented greater $(\mathrm{P}<0.05)$ excretions of uric acid $(\mathrm{mmol} / \mathrm{L})$, purine derivatives and microbial $\mathrm{CP}$ production (CPmic) than animals fed at maintenance level (Table 3). This is due to the greater input of nutrients supplied by the diet of animals with free access, in comparison with those kept at maintenance regimen, with consequent greater excretion of purine derivatives in the urine.

It is likely that the non-observance of differences $(\mathrm{P}>0.05)$ in microbial production of animals receiving 225 and $450 \mathrm{~g} / \mathrm{kgDM}$ concentrate occurred because the $\mathrm{CP}$ and TDN intakes did not differ $(\mathrm{P}>0.05)$ between these treatments (Table 4) either. Hoover \& Stokes (1991) verified that microbial protein production is directly proportional to rumen-degradable protein intake. As the feeds in both diets were the same, with only amounts varying, even with higher level of urea in the diet containing $225 \mathrm{~g} / \mathrm{kgDM}$ concentrate (Table 2), probably there was no significant difference in the input of rumen-degradable protein supplied by the two diets.

The manipulation of roughage and concentrate ratios in the diet has been pointed as a way to maximize microbial synthesis efficiency (Clark et al., 1992). The same authors also stated that energy availability could be limiting to microbial growth, so that the organic matter to be fermented

Table 3 - Digestibility and microbial production of the experimental diets (Experiment I)

\begin{tabular}{|c|c|c|c|c|c|c|}
\hline \multirow[t]{2}{*}{ Item $^{1}$} & \multicolumn{3}{|c|}{ Diet } & \multicolumn{2}{|c|}{$\mathrm{P}$ value } & \multirow[t]{2}{*}{ CV $(\%)$} \\
\hline & Maintenance & $225 \mathrm{~g} / \mathrm{kgDM}$ & $450 \mathrm{~g} / \mathrm{kgDM}$ & $\mathrm{CL}^{1}$ & Restriction $^{2}$ & \\
\hline \multicolumn{7}{|l|}{ Digestibility (\%) } \\
\hline Crude protein & 70.94 & 71.62 & 71.51 & 0.943 & 0.662 & 2.4 \\
\hline Ether extract & 90.82 & 93.93 & 87.10 & 0.065 & 0.867 & 2.5 \\
\hline $\mathrm{NDF}_{\text {ap }}$ & 61.78 & 54.17 & 55.32 & 0.651 & 0.065 & 4.7 \\
\hline \multicolumn{7}{|l|}{ Purine derivates and microbial production } \\
\hline Urine volume (L/day) & 5.14 & 3.52 & 6.04 & 0.338 & 0.854 & 50.5 \\
\hline Alantoin $(\mathrm{mmol} / \mathrm{L})$ & 16.71 & 21.63 & 21.76 & 0.969 & 0.177 & 17.2 \\
\hline Uric acid $(\mathrm{mmol} / \mathrm{L})$ & 0.54 & 2.34 & 1.49 & 0.066 & 0.020 & 19.4 \\
\hline Purine derivates excretion ( $\mathrm{mmol} /$ day) & 83.10 & 114.28 & 129.68 & 0.117 & 0.016 & 6.5 \\
\hline Microbial protein production (g/day) & 277.97 & 420.67 & 516.00 & 0.153 & 0.017 & 8.1 \\
\hline
\end{tabular}


increased, and hence the protein synthesis. However, no differences were observed for either CP or TDN intake (Table 4) between the concentrate levels utilized, which contributes to explaining the lack of difference $(\mathrm{P}>0.05)$ in microbial $\mathrm{CP}$ production and microbial synthesis efficiency between the concentrate levels.

The mean value of microbial efficiency of this study $(116.78 \mathrm{~g} \mathrm{CPmic} / \mathrm{kg}$ TDN) is close to that estimated by BR-CORTE (Valadares Filho et al., 2010), which is $120 \mathrm{~g} \mathrm{CPmic} / \mathrm{kg}$ TDN.

No interaction was observed $(\mathrm{P}>0.05)$ between the concentrate level and feedlot period for any of the intake and performance characteristics evaluated (Table 4) in experiment II. The feedlot periods were compared as qualitative features, once they represent the averages within the period, and not a characteristically continuous effect.

The concentrate level did not affect $(\mathrm{P}>0.05)$ DM intake (Table 4); however, Silva et al. (2002) report that DM intake, in relation to concentrate levels in the diet varies, depending on the breed and the diet supplied, among other factors.

When presented as $\mathrm{kg} /$ day, DM intake was higher $(\mathrm{P}<0.05)$ in the last period, in relation to the first (Table 4), which is explained by the greater weight of animals in the period of 126 to 168 days, in relation to the period of 0 to 42 days. However, when presented in function of BW, there is an inversion in the DM intake values, so that the latter showed higher $(\mathrm{P}<0.05)$ in the first period, in relation to the others, following the same trend of average daily gain (ADG).

The reduction in DM intake per weight unit with the increase in the animal weight can be explained by the reduction in the maintenance requirements of the animal, which occurs due to decrease in the proportion of organs that demand more energy, such as the liver and gastrointestinal tract (Seal \& Reynolds, 1993), in relation to the body of the animal, concerning the increase in its size. Another factor that might have contributed to such decrease in intake is the increase in the production of hormone leptin by animals that start to deposit bigger amount of fat tissue (Houseknecht et al., 1998).

No differences were observed $(\mathrm{P}>0.05)$ for $\mathrm{CP}$ intake between the concentrate levels and the periods of confinement. The non-significance between the concentrate levels happened because there were no differences in DM intake and because the diets utilized has the same amount of protein (Table 2). Variations in the behavior of TDN intake and $\mathrm{CP}$ intake values different from variations in DM intake must have occurred in function of animals selectivity of the diet in the trough.

Following the same trend of DM intake, TDN intake also did not differ $(\mathrm{P}>0.05)$ between the concentrate, levels, regardless of the form of expression, but differed $(\mathrm{P}<0.05)$ between the feedlot periods, with inversion when presented in $\mathrm{kg} /$ day or $\% \mathrm{BW}$. This is due to the fact that $\mathrm{DM}$ intake was not different $(\mathrm{P}>0.05)$ between the concentrate levels and that the TDN contents of the diets utilized were similar (Table 2). The decrease TDN intake in percentage of BW from the first to the second, and from the second to the third periods of feedlot may be considered a result of the decrease in DM intake and of the uniformity of diets throughout all the evaluation period. The fact that DM intake did not differ $(\mathrm{P}<0.05)$ also seems to be a result from selectivity of animals to the diet in the trough.

Table 4 - Dry matter intake and performance of Nellore heifers fed two concentrate levels in different periods of feedlot (Experiment II)

\begin{tabular}{|c|c|c|c|c|c|c|c|c|c|}
\hline \multirow[t]{2}{*}{ Item $^{1}$} & \multicolumn{2}{|c|}{ Concentrate level } & \multicolumn{4}{|c|}{ Feedlot period (days) ${ }^{1}$} & \multicolumn{3}{|c|}{$P$ value ${ }^{2}$} \\
\hline & $225 \mathrm{~g} / \mathrm{kgDM}$ & $450 \mathrm{~g} / \mathrm{kgDM}$ & $0-42$ & $42-84$ & $84-126$ & $126-168$ & $\mathrm{CL}$ & FP & $\mathrm{CL} \times \mathrm{FP}$ \\
\hline \multicolumn{10}{|l|}{ Intake (kg/day) } \\
\hline DM & $4.96 \pm 0.32$ & $5.56 \pm 0.32$ & $4.94 \pm 0.22 b$ & $5.10 \pm 0.23 \mathrm{ab}$ & $5.32 \pm 0.24 \mathrm{ab}$ & $5.67 \pm 0.28 \mathrm{a}$ & 0.203 & 0.036 & 0.515 \\
\hline $\mathrm{CP}$ & $0.75 \pm 0.05$ & $0.82 \pm 0.05$ & $0.75 \pm 0.03$ & $0.77 \pm 0.03$ & $0.79 \pm 0.04$ & $0.82 \pm 0.04$ & 0.298 & 0.058 & 0.877 \\
\hline $\mathrm{NDF}_{\mathrm{ap}}$ & $2.24 \pm 0.13$ & $1.99 \pm 0.13$ & $1.91 \pm 0.09 \mathrm{~d}$ & $2.03 \pm 0.10 \mathrm{c}$ & $2.18 \pm 0.10 \mathrm{~b}$ & $2.33 \pm 0.10 \mathrm{a}$ & 0.203 & $<0.001$ & 0.573 \\
\hline $\mathrm{TDN}^{\mathrm{ap}}$ & $3.71 \pm 0.24$ & $4.16 \pm 0.24$ & $3.68 \pm 0.17 \mathrm{c}$ & $3.86 \pm 0.17 b$ & $3.99 \pm 0.18 \mathrm{ab}$ & $4.21 \pm 0.19 \mathrm{a}$ & 0.197 & 0.002 & 0.502 \\
\hline \multicolumn{10}{|c|}{ Intake ( $\mathrm{g} / \mathrm{kg}$ of body weight/day) } \\
\hline DM & $21.5 \pm 0.7$ & $23.0 \pm 0.7$ & $25.9 \pm 0.5 \mathrm{a}$ & $22.3 \pm 0.6 \mathrm{~b}$ & $20.7 \pm 0.6 \mathrm{~b}$ & $19.9 \pm 0.9 b$ & 0.130 & $<0.001$ & 0.701 \\
\hline $\mathrm{CP}$ & $9.6 \pm 0.3$ & $8.1 \pm 0.3$ & $10.0 \pm 0.2 \mathrm{a}$ & $8.9 \pm 0.2 b$ & $8.4 \pm 0.2 \mathrm{c}$ & $8.1 \pm 0.3 c$ & 0.002 & $<0.001$ & 0.779 \\
\hline $\mathrm{NDF}_{\text {ap }}$ & $15.9 \pm 0.5$ & $17.2 \pm 0.5$ & $19.3 \pm 0.4 \mathrm{a}$ & $16.9 \pm 0.4 b$ & $15.4 \pm 0.4 \mathrm{c}$ & $14.5 \pm 0.6 \mathrm{c}$ & 0.101 & $<0.001$ & 0.662 \\
\hline \multicolumn{10}{|l|}{ Performance } \\
\hline ADG (kg/day) & $0.74 \pm 0.05$ & $0.90 \pm 0.05$ & $1.01 \pm 0.04 \mathrm{a}$ & $0.79 \pm 0.05 b$ & $0.69 \pm 0.06 \mathrm{~b}$ & $0.81 \pm 0.08 \mathrm{~b}$ & 0.046 & $<0.001$ & 0.907 \\
\hline FE & $0.15 \pm 0.01$ & $0.17 \pm 0.01$ & $0.20 \pm 0.01 \mathrm{a}$ & $0.16 \pm 0.01 \mathrm{~b}$ & $0.13 \pm 0.01 \mathrm{c}$ & $0.14 \pm 0.01 b c$ & 0.234 & $<0.001$ & 0.800 \\
\hline
\end{tabular}

DM - dry matter intake; CP - crude protein; $\mathrm{NDF}_{\text {ap }}$ - neutral detergent fiber corrected for ash and protein; TDN - total digestible nutrients; $\mathrm{ADG}$ - average daily gain; $\mathrm{FE}$ - ADG/DM intake.

${ }^{1}$ Means in the rows, followed by different letters are different $(\mathrm{P}<0.05)$ by Tukey-Kramer test.

${ }^{2} \mathrm{CL}$ - concentrate level and FP - period of feedlot. 
The intake of neutral detergent fiber corrected for ash and protein $\left(\mathrm{NDF}_{\mathrm{ap}}\right)$ did not differ $(\mathrm{P}>0.05)$ between the concentrate levels when presented in $\mathrm{kg} /$ day, but did differ $(\mathrm{P}<0.05)$ between them when presented in $\mathrm{BW}$ percentage. This difference may not have been clear when presented as gross value, because animals from the level of $450 \mathrm{~g} / \mathrm{kgDM}$ concentrate gained more weight and became bigger than animals from treatment with $225 \mathrm{~g} / \mathrm{kg} / \mathrm{DM}$ concentrate over time, which made them also present numerically higher DM intake, which might have led to higher $\mathrm{NDF}_{\text {ap }}$ intake and approximation of $\mathrm{NDF}_{\text {ap }}$ intake between the two treatments. When compared in function of BW, the difference $(\mathrm{P}<0.05)$ found is explained by the fact that diets presented different $\mathrm{NDF}_{\text {ap }}$ content.

Detmann et al. (2003) worked with a database composed of 45 scientific studies and 181 means of treatments for feedlot cattle at tropical conditions, and assessed NDF intake in these conditions, finding maximum NDF intake of $1.19 \% \mathrm{BW}$, which was similar to the proposition of Mertens (1987), of 1.2\% BW. However, unlike Mertens (1987), Detmann et al. (2003) observed inconstant behavior of NDF intake during the phase of physical control, which suggests that the transition into the phase of metabolic control may be represented by an interval, and not exactly by an inversion point of regulatory mechanisms.

Based on the information found in the literature, it is denoted that the intake of animals in this experiment seems not to have been controlled by filling mechanisms, being regulated, hence, by the genetic potential of the animal. The animal, according to Allen (2000), tries to keep a status of energy supply continuously, directing its intake so that it can meet homeostatically and homeorhetically the model of skeletal, muscular, and other metabolically active tissues growth of its body.

Although no differences were observed $(\mathrm{P}>0.05)$ in TDN and $\mathrm{CP}$ intake or feed efficiency between the concentrate levels (Table 4), Nellore heifers fed $450 \mathrm{~g} / \mathrm{kgDM}$ concentrate had greater $(\mathrm{P}<0.05)$ average daily gain $(\mathrm{ADG})$ than those fed $225 \mathrm{~g} / \mathrm{kgDM}$ concentrate (Table 4). This is because, biologically, ADG can be in function of these and also of other variables; its increase may not have occurred proportionally to the increase in TDN and feed efficiency, so that not differences were observed in these variables, contrarily to what was verified in ADG.

The variations verified between the feedlot periods showed that ADG was higher $(\mathrm{P}<0.05)$ in the period of 0 to 42 days, in comparison with the others. Drouillard \& Kuhl (1999) suggested that, depending on the previous feeding management, usually made up of pastures, there is higher animal performance in the first feedlot periods, as a result of compensatory gain. The animals from this experiment went through an adaptation period of 21 days; however, there may have been compensatory gain effect even after this period.

Another factor that may have contributed to greater ADG in the first period is the fact that younger cattle are more biologically efficient; for example, 11.6-month animals that are $7 \%$ more biologically efficient than 16.5 -month animals, in function of differences in tissue deposition (Williams et al., 1995). It can be seen also that even though the intake was higher, feed efficiency was also higher in the first periods, in relation to the rest (Table 4).

The non-significance $(\mathrm{P}>0.05)$ for feed efficiency between the concentrate levels may have been a result from the high digestibility of diets (Table 3 ). On the other hand, the higher $\mathrm{FE}(\mathrm{P}<0.05)$ found for the period of 0 to 42 days in relation to the others, and for the period of 42 to 84 days, in relation to the period of 84 to 126 days seems to be reasoned by the size and age of animals. With increase in weight, animals start to deposit more fat tissue in detriment to the protein deposition rate (Fox \& Black, 1984; Williams et al., 1995), and although fat deposition is energetically more efficient than that of protein (Geay, 1984; Chizzotti et al., 2008), it requires more amount of energy consumed per $\mathrm{kg}$ of tissue deposited in comparison with the lean tissue in function of the greater energy density of $1 \mathrm{~kg}$ fat tissue in comparison with $1 \mathrm{~kg}$ lean tissue.

In carcass characteristics (Table 5), the feedlot time constituted quantitative factor, unlike the factor feedlot time in performance and dry matter intake characteristics (Table 4), once the data referring to carcass characteristics are originated from slaughter performed exactly at the times presented.

No interaction $(\mathrm{P}>0.05)$ was observed between the concentrate level and feedlot time for any of the carcass characteristics evaluated (Table 5). Multiple regression equations were tested for the carcass variables in function of empty body weight (EBW) and concentrate level. Only significance $(\mathrm{P}<0.05)$ of the EBW effect was found for variables backfat thickness and flank percentage, given that for backfat thickness, the intercept was not significant $(\mathrm{P}>0.05)$ and the model which presented best correlation coefficient $\left(\mathrm{r}^{2}\right)$ was that in function of $\mathrm{EBW}^{2}$. This way, based on thes results (Table 5) and on the regressions where EBW was utilized, the equations or means that best describe the variables studied were developed (Table 6).

Since the sum of the percentages of the five basic cuts yields a total of $100 \%$ when there is variation in the percentage of one of the cuts, as in the case of flank (Table 6), there should also be variation in the proportion of the other 
Table 5 - Carcass characteristics of Nellore heifers fed two concentrate levels in different periods of feedlot (experiment II)

\begin{tabular}{|c|c|c|c|c|c|c|c|c|c|c|c|c|}
\hline \multirow[t]{2}{*}{ Item $^{1}$} & \multicolumn{2}{|c|}{ Concentrate level } & \multicolumn{4}{|c|}{ Feedlot time (days) } & \multicolumn{5}{|c|}{$P$ value } & \multirow[t]{2}{*}{$\mathrm{CV}(\%$} \\
\hline & $225 \mathrm{~g} / \mathrm{kgDM}$ & $450 \mathrm{~g} / \mathrm{kgDM}$ & 42 & 84 & 126 & 168 & $\mathrm{CL}$ & $\mathrm{FT}_{\mathrm{L}}$ & $\mathrm{FT}_{\mathrm{Q}}$ & $\mathrm{FT}_{\mathrm{C}}$ & $\mathrm{CL} \times \mathrm{FP}$ & \\
\hline \multicolumn{13}{|c|}{ Basic cuts $(\%)$} \\
\hline Top sirloin & 18.99 & 19.02 & 19.49 & 18.71 & 18.94 & 18.89 & 0.956 & 0.498 & 0.489 & 0.585 & 0.899 & 5.30 \\
\hline Round & 30.03 & 30.15 & 30.37 & 30.97 & 30.02 & 29.00 & 0.869 & 0.159 & 0.295 & 0.665 & 0.849 & 4.83 \\
\hline Chuck & 21.24 & 20.28 & 21.19 & 19.55 & 21.01 & 21.29 & 0.242 & 0.619 & 0.244 & 0.245 & 0.580 & 7.33 \\
\hline Shoulder & 17.94 & 18.38 & 17.64 & 18.56 & 18.26 & 18.19 & 0.332 & 0.506 & 0.288 & 0.478 & 0.766 & 4.76 \\
\hline Flank & 11.80 & 12.16 & 11.31 & 12.21 & 11.77 & 12.64 & 0.431 & 0.107 & 0.969 & 0.211 & 0.145 & 7.28 \\
\hline \multicolumn{13}{|c|}{ Group cuts yield (\%) } \\
\hline Hindquarter & 49.02 & 49.17 & 49.86 & 49.68 & 48.96 & 47.88 & \multirow{2}{*}{0.816} & \multirow{2}{*}{0.048} & \multirow{2}{*}{0.501} & \multirow{2}{*}{0.951} & \multirow{2}{*}{0.902} & 2.60 \\
\hline Forequarter & 50.98 & 50.83 & 50.14 & 50.32 & 51.04 & 52.12 & & & & & & 2.51 \\
\hline \multicolumn{13}{|c|}{ Cold carcass yield and backfat thickness } \\
\hline CCY (\%) & 53.19 & 54.74 & 52.39 & 54.52 & 55.50 & 53.45 & 0.026 & 0.140 & 0.006 & 0.474 & 0.239 & 2.10 \\
\hline $\mathrm{BT}(\mathrm{mm})$ & 2.34 & 2.74 & 1.05 & 1.99 & 2.05 & 5.06 & 0.609 & 0.005 & 0.201 & 0.428 & 0.2465 & 58.30 \\
\hline
\end{tabular}

$\mathrm{DM}$ - dry matter; CV - coefficient of variation; $\mathrm{CCY}$ - cold carcass yield; CL - concentrate level; $\mathrm{FT}_{\mathrm{L}}$ - linear effect for feedlot time; $\mathrm{FT}_{\mathrm{Q}}$ - quadratic effect for feedlot time; $\mathrm{FT}_{\mathrm{C}}$ - cubic effect for feedlot time; BT - backfat thickness.

${ }^{1}$ Hindquarter $=$ top sirloin + round; Forequarter $=$ chuck + shoulder + flank.

cuts. However, the results found show that this variation does not occur in a way that can be significantly $(\mathrm{P}<0.05)$ explained by influence of one of the variables studied (EBW, feedlot time and concentrate level).

For backfat thickness, the equation generated by means of regression in function of EBW seemed more suitable for the biological behavior of this variable (Table 6), and no equation generated in function of feedlot time was presented; feedlot time presented linear and quadratic effects significant for backfat thickness (Table 5).

No differences were observed ( $\mathrm{P}>0.05)$ for yields of any of the basic cuts in function of feedlot time, with significance $(\mathrm{P}<0.05)$ only found for proportion of flank in function of EBW (Table 5). However, when basic cuts were grouped in forequarter and hindquarter, linear increase was observed in forequarter yield, with consequent decrease in hindquarter proportion, as a consequence of the amount of time the animals were confined. Hindquarter cuts have more commercial value and, therefore, this decrease in function of feedlot time would become, someway, harmful to the commercial value of the carcass. The cuts ratios were similar to those found by Marcondes et al. (2008) for Nellore females heavier than those in this experiment, with only round and hindquarter values being numerically different, with superiority for the animals in this experiment.

Heifers fed $450 \mathrm{~g} / \mathrm{kgDM}$ concentrate presented better carcass yield $(\mathrm{P}<0.05)$ than those fed $225 \mathrm{~g} / \mathrm{kgDM}$ concentrate in the diet (Table 5). This result may be related to a greater $\mathrm{NDF}_{\mathrm{ap}}$ intake of animals from the treatment with $225 \mathrm{~g} / \mathrm{kg}$ DM concentrate (Table 4). Therefore, these animals might have had more development of the gastrointestinal tract, which, according to Seal \& Reynolds (1993), represents from 8 to $14 \%$ of the total weight of the animal, making the viscera volume increase and the carcass yield. Paulino et al. (2008) and Marcondes et al. (2008) did not observe any differences in carcass yield of females under different levels of concentrate.

Quadratic effect and subsequent decrease were observed in cold carcass yield, with maximum yield at 114 days of feedlot. A possible compensatory gain effect, which may have happened in the first stages of feedlot, coupled with the increase in internal fat deposition, can explain these values (Tables 5 and 6). In the study of Sainz et al. (1995), animals fed ad libitum with diets with low level of concentrate had increase in the gastrointestinal tract content weight in percentage of EBW from 237 to $327 \mathrm{~kg}$ (weight range similar to that in which there was decrease in cold carcass yield in this study), which means reduction in carcass yield. Super-young heifers had lower carcass yield than males of the same age (Vaz et al., 2010), for presenting higher amount of internal fat and because the weight of the mammary gland in females is greater than the weight of the reproductive system in males. This way, internal fat deposition and growth of mammary gland, along with an effect of compensatory gain at the beginning of the feedlot period, could explain the decrease in carcass yield of animals slaughtered at 168 days in feedlot.

The backfat thickness values found suggest that young Nellore females, when confined at the post-weaning phase, may reach viability for slaughter from the viewpoint of backfat to weights lower than the normally suggested. By the equation presented (Table 6), Nellore females would reach $3 \mathrm{~mm}$ backfat thickness with $270 \mathrm{~kg}$ body weight (taking EBW/BW $=0.8941$, observed data), which would 
Table 6 - Equations or means that best describe the basic cuts, cold carcass yield and backfat thickness in Nellore heifers

\begin{tabular}{ll}
\hline Item & \multicolumn{1}{c}{ Equation } \\
\hline Top sirloin (\%) & $\hat{\mathrm{Y}}=19.01$ \\
Round (\%) & $\hat{\mathrm{Y}}=30.09$ \\
Chuck (\%) & $\hat{\mathrm{Y}}=20.76$ \\
Shoulder (\%) & $\hat{\mathrm{Y}}=18.18$ \\
Flank (\%) & $\hat{\mathrm{Y}}=\mathrm{EBW} \times 0.1512+8.482\left(\mathrm{R}^{2}=0.32\right)$ \\
& $\hat{\mathrm{Y}}=50.76-0.0158 \times \mathrm{FT}\left(\mathrm{R}^{2}=0.08\right)$ \\
Hindquarter (\%) & $\hat{\mathrm{Y}}=49.24+0.0158 \times \mathrm{FT}\left(\mathrm{R}^{2}=0.08\right)$ \\
Forequarter (\%) & $225 \mathrm{~g} / \mathrm{kgDM}$ of concentrate: $\hat{\mathrm{Y}}=46.93+0.134 \times \mathrm{FT}^{2}-0.00059 \times \mathrm{FT}^{2}\left(\mathrm{R}^{2}=0.16\right)$ \\
CCY (\%) & $450 \mathrm{~g} / \mathrm{kgDM}$ of concentrate: $\hat{\mathrm{Y}}=48.47+0.134 \times \mathrm{FT}^{2}-0.00059 \times \mathrm{FT}^{2}\left(\mathrm{R}^{2}=0.16\right)$ \\
& $\hat{\mathrm{Y}}=\mathrm{EBW} \times 0.00005170\left(\mathrm{R}^{2}=0.82\right)$ \\
\hline BT $(\mathrm{mm})$ &
\end{tabular}

CCY - cold carcass yield; FT - feedlot time (days); EBW - empty body weight (kg); BT - backfat thickness (mm); DM - dry matter.

consist of an animal of about 10 arrobas of carcass (considering the cold carcass yield values presented in Table 5).

Females normally tend to present fat deposition earlier than castrated and non-castrated males (Berg \& Butterfield, 1976; Coutinho Filho et al., 2006; Paulino et al., 2008; Marcondes et al., 2008). Thus, females tend to reach maturity at lower weights than males. Some authors have reported that slaughter of too young animals may increase the cost per kg of improved carcass, because they require more manpower (Restle et al., 1996; Costa et al., 2002). On the other hand, the finishing of younger animals can increase capital turnover and generate softer meat, especially due to the lower collagen content (Luckett et al., 1975).

\section{Conclusions}

Nellore heifers in feedlot during the growth phase receiving diet with $450 \mathrm{~g} / \mathrm{kg}$ DM concentrate and corn silage as roughage present better performance than those fed $225 \mathrm{~g} / \mathrm{kg}$ DM concentrate. Average daily gain, feed efficiency, dry matter intake, total digestible nutrients intake, crude protein intake and neutral detergent fiber intake, when expressed as percentage of body weight, are affected by feedlot time, and are greater in the first periods of feedlot. The apparent digestibility of dry matter and of nutrients, as well as microbial protein synthesis efficiency do not suffer significant variations in function of the level of concentrate in the diet, when young Nellore heifers are fed 225 or $450 \mathrm{~g} / \mathrm{kg}$ DM concentrate in the diet.

\section{References}

AKAIKE, H. A new look at the statistical model identification. IEEE Transactions on Automatic Control, v.19, n.6, p.716-723, 1974.

ALLEN, M.S. Effects of diet on short-term regulation of feed intake by lactating dairy cattle. Journal of Dairy Science, v.83, n.7, p.1598-1624, 2000.

BARBOSA, A.M.; VALADARES, R.F.D.; VALADARES FILHO, S.C. et al. Endogenous fraction and urinary recovery of purine derivates obtained by different methods in Nellore cattle. Journal of Animal Science, v.89, n.2, p.510-519, 2011.

BERG, R.T.; BUTTERFIELD, R.M. New concepts of cattle growth. Sydney: Sydney University Press, 1976. 240p.

CHEN, X.B.; GOMES, M.J. Estimation of microbial protein supply to sheep and cattle based on urinary excretion of purine derivatives - an overview of technical details (Occasional publication). International Feed Resources Unit. Bucksburnd, Aberdeen: Rowett Research Institute, 1992. 21p.

CHIZZOTTI, M.L.; TEDESCHI, L.O.; VALADARES FILHO, S.C. A meta-analysis of energy and protein requirements for maintenance and growth of Nellore cattle. Journal of Animal Science, v.86, n.7, p.1588-1597, 2008.

CLARK, J.H.; KLUSMEYER, T.H.; CAMERON, M.R. Microbial protein synthesis and flows of nitrogen fractions to the duodenum of dairy cows. Journal of Dairy Science, v.75, n.8, p.2304-2323, 1992.

COSTA, E.C.; RESTLE, J.; VAZ, F.N. et al. Características da carcaça de novilhos Red Angus superprecoces abatidos com diferentes pesos. Revista Brasileira de Zootecnia, v.31, n.1, p.119-128, 2002 .

COUTINHO FILHO, J.L.; PERES, R.M.; JUSTO, C.L. Produção de carne de bovinos contemporâneos, machos e fêmeas, terminados em confinamento. Revista Brasileira de Zootecnia, v.35, n.5, p.2043-2049, 2006.

DETMANN, E.; VALADARES FILHO, S.C. On the estimation of non-fibrous carbohydrates in feeds and diets. Arquivo Brasileiro de Medicina Veterinária e Zootecnia, v.62, n.4, p.980-984, 2010 .

DETMANN, E.; QUEIROZ, A.C.; CECON, P.R. et al. Consumo de fibra em detergente neutro por bovinos em confinamento. Revista Brasileira de Zootecnia, v.32, n.6, p.1763-1777, 2003. 
DROUILLARD, J.S.; KUHL, G.L. Effects of previous grazing nutrition and management on feedlot performance of cattle. Journal of Animal Science, v.77, n.2, p.133-146, 1999.

FOX, D.G.; BLACK, J.R. A system for predicting body composition and performance of growing cattle. Journal of Animal Science, v. 58, n. 3, p.725-739, 1984.

FUJIHARA, T.; ORSKOV, E.R.; REEDS, P.J. et al. The effect of protein infusion on urinary excretion of purine derivates in ruminants nourished by intragastric nutrition. Journal of Agricultural Science, v.109, n.1, p.7-12, 1987.

GEAY, Y. Energy and protein utilization in growing cattle. Journal of Animal Science, v.58, n.3, p.766-778, 1984.

HOOVER, W.H.; STOKES, S.R. Balancing carbohydrates and proteins for optimum rumen microbial yield. Journal of Dairy Science, v.74, n.10, p.3630-3644, 1991.

HOUSEKNECHT, K.L.; BAILE, C.A.; MATTERI, R.L. et al. The biology of leptin: A review. Journal of Animal Science, v.76, n.1, p.1405-1420, 1998.

INSTITUTO BRASILEIRO DE GEOGRAFIA E ESTATÍSTICA IGBE. [2011]. Indicadores IBGE - Estatística da Produção Pecuária. Available at: <http://www.ibge.gov.br/home/estatistica/ indicadores/agropecuaria/producaoagropecuaria/abate-leite-couroovos_201003_publ_completa.pdf> Accessed on: Feb. 17, 2011.

LUCKETT, R.L.; BIDNER, T.D.; ICAZA, E.A. et al. Tenderness studies in straightbred and crossbred steers. Journal of Animal Science, v.40, n.3, p.468-475, 1975.

MARCONDES, M.I.; VALADARES FILHO, S.C.; PAULINO, P.V.R. et al. Consumo e desempenho de animais alimentados individualmente ou em grupo e características de carcaça de animais Nelore de três classes sexuais. Revista Brasileira de Zootecnia, v.37, n.12, p.2243-2250, 2008.

MERTENS, D.R. Predicting intake and digestibility using mathematical models of ruminal function. Journal of Animal Science, v.64, n.5, p.1548-1558, 1987.

NATIONAL RESEARCH COUNCIL - NRC. Nutrient requirements of dairy cattle. 7.ed. Washington, DC: National Academy Press, 2001. 362p.

PAULINO, P.V.R.; VALADARES FILHO, S.C.; DETMANN, E. et al. Desempenho produtivo de bovinos Nelore de diferentes classes sexuais alimentados com dietas contendo dois níveis de oferta de concentrado. Revista Brasileira de Zootecnia, v.37, n.6, p.1079-1087, 2008
PÖTTER, L.; LOBATO, J.F.P.; MIELITZ NETTO, C.G. Produtividade de um modelo de produção para novilhas de corte primíparas aos dois, três e quatro anos de idade. Revista Brasileira de Zootecnia, v.27, n.3, p.613-615, 1998.

RESTLE, J.; KEPLIN, L.A.S.; VAZ, F.N. et al. Qualidade da carne de novilhos Charolês confinados e abatidos com diferentes pesos. Ciência Rural, v.26, n.3, p.463-466, 1996.

ROCHA, M.G.; LOBATO, J.F.P. Avaliação do desempenho reprodutivo de novilhas de corte primíparas aos dois anos de idade. Revista Brasileira de Zootecnia, v.31, n.3, p.1388-1395, 2002 (supl.)

SAINZ, R.D.; DE LA TORRE, F.; OLTJEN, J.W. Compensatory growth and carcass quality in growth-restricted and refed beef steers. Journal of Animal Science, v.73, n.10, p.2971-2979, 1995.

SEAL, C.J.; REYNOLDS, C.K. Nutritional implications of gastrointestinal and liver metabolism in ruminants. Nutrition Research Reviews, v.6, n.1, p.185-208, 1993.

SILVA, D.J.; QUEIROZ, A.C. Análise de alimentos (métodos químicos e biológicos). 3.ed. Viçosa, MG: Imprensa Universitária Universidade Federal de Viçosa, 2002. 165p.

SILVA, F.F.; VALADARES FILHO, S.C.; ÍTAVO, L.C.V. et al Desempenho produtivo de novilhos Nelore, na recria e na engorda, recebendo dietas com diferentes níveis de concentrado e proteína. Revista Brasileira de Zootecnia, v.31, n.1, p.492-502, 2002 (supl.)

UNDERSANDER, D.; MERTENS, D.R.; THIEX, N. [1993]. Forage analyses procedures. Omaha: National Forage Testing Association. 135p. Available at: <http://www.foragetesting.org/ lab_procedure/labpro.pdf $>$. Accessed on: Feb. 18, 2011.

VALADARES FILHO, S.C.; MARCONDES, M.I.; CHIZZOTTI, M.L. Nutrient requirements of Zebu beef cattle - BR CORTE. 2.ed. Viçosa, MG: UFV, Suprema Gráfica Ltda., 2010. 185p.

VAN SOEST, P.J.; ROBERTSON, J.B.; LEWIS, B.A. Methods for dietary fiber, neutral detergent fiber, and nonstarch polysaccharides in relation to animal nutrition. Journal of Dairy Science, v.74, n.10, p.3583-3597, 1991.

VAZ, F.N.; RESTLE, J.; ARBOITTE, M.Z. et al. Fatores relacionados ao rendimento de carcaça de novilhos ou novilhas superjovens, terminados em pastagem cultivada. Ciência Animal Brasileira v.11, n.1, p.53-61, 2010.

WILliAMS, C.B.; BENNETT, G.L.; KEELE, J.W. Simulated influence of postweaning production system on performance of different biological types of cattle: III. Biological efficiency. Journal of Animal Science, v.73, n.3, p.686-698, 1995. 